\title{
Vascular Implants Reinforced with Natural Silk Yarns
}

\author{
Viktorija Kancevicha ${ }^{1}$, Andreys Lukyanchikovs ${ }^{2},{ }^{1-2}$ Riga Technical University, Institute of Textile Materials \\ Technologies and Design
}

\begin{abstract}
In the course of this research work woven synthetic prosthesis reinforced with natural silk yarns was designed and manufactured. Biomechanical properties of surgical natural silk were studied during designing of the structure of the walls of the prosthesis. The experiment gave good data of elasticity and strain properties in a process of laboratory testing of samples of natural fibers. The previous practical experience was also used, for example, various vascular prostheses made from polyurethane complex yarns and polyester monofilaments. As a result, the authors of the scientific work proposed a combined wall structure of vascular prosthesis, consisting of polyester, polyurethane, and natural silk surgical yarns. After the implantation of the synthetic prosthesis reinforced with natural silk yarns, these natural silk yarns completely dissolve in the body for several years. Living tissue is gradually growing into the walls of synthetic prosthesis, replacing dissolved natural silk yarns. Experimental tests confirmed that a modulus of elasticity of innovative prosthesis is close to modulus of elasticity of natural blood vessels. The innovative structure of blood vessel prosthesis combined with such parameters can provide a long-term normal hemodynamics.
\end{abstract}

Keywords: Natural silk yarns, vascular implant, woven vascular prosthesis.

\section{INTRODUCTION}

The heart is the main organ of the vascular system. It continuously performs the pumping function. The human heart does more than 100000 beats per day (an average of 70 beats per one minute), during this time it can pump large amounts of blood (approximately 7000 liters).

During the process of blood pulsing diameter of a natural blood vessel is extended from $10 \%$ till $12 \%$. The diameter of vascular implants used in the surgery extends only from $3 \%$ to $5 \%$. This means that the biomechanical properties of such implants cannot fully ensure the blood wave move in the vascular system. This factor creates tension in the anastomosis and it can break the connection place of the prosthesis with a natural blood vessel. This intense exposure can cause hyperplasia of intima and aneurysm, as well as have a negative impact on the overall vascular system. Synthetic implants are used to treat a variety of diseases associated with impaired patency of blood flow through the main blood vessel, when the heart muscle and other organs do not receive enough oxygen and nutrition. Usually, this pathology is revealed in the form of deposits on the walls of the blood vessel or formation of plaques. In this case, sclerotic changes occur in some parts of the vascular system. Then the inner diameter of the lumen of blood vessel becomes narrow. In the case of a large stage of sclerosis cardio-surgeons often make an operation using artificial implants.

Different types of textile materials are widely used in various types of heart surgery. For example, textiles actively used for the manufacturing of artificial valves and as a special suture material for the heart [1-3].

\section{II.PRACTICAL EXPERIENCE OF DIAGNOSTICS}

Method of x-ray of the pathology of the blood vessels is considered to be quite complex. The most accurate images are obtained after injection of contrast material in coronary artery and others. In this case, the surgeon sees all the changes in the diameter of lumen and blockage of the blood vessels. After the diagnosis the doctor determines the method of treatment of the patient. Usually the doctor makes the decision to do surgery if other methods are not effective.

For these purposes an implant made of composite structural material is needed which has the necessary properties to solve the problems of vascular surgery, such as restoring the overall functionality of the body, replacing a section of atherosclerotic damaged blood vessel.

The morphological basis of blood vessel walls is unique elastic collagen frame or skeleton. The outer shell of this skeleton provides a process of the ingrowth of capillaries, promotes the formation of proximal and distal sites, as well as dampens wave pounding of blood pulsation.

Currently, surgeons use vascular implants that are not able to function similarly to nonlinear elastic natural blood vessel walls. Such implants are not capable of adequately pulsating under conditions of real hemodynamics.

Manufacturers of vascular implants often make the synthetic prosthesis as a tubular material (woven, knitted, braided) and then they make a wavy or goffered wall on this product during a subsequent process of finishing. Goffered vascular prosthesis can promote the blood flow turbulence in the segment of lumen where it is implanted. This goffered structure of the implant changes the speed of the blood flow and changes the blood pressure on the walls of the implant and other vessels. Unwanted turbulent processes of the blood contribute to the formation of organic deposits on the walls of the prosthesis and consequently contribute to the formation of blood clots in the vascular channel. Goffered implant may well become deformed in the longitudinal direction because of wavy surfaces of walls. In the process of elongation the elastic parameters change also in radial direction. Prosthesis with this structure sooner or later suffers from thrombosis. Such lesions are found in the practice surgery in $25 \%$ of cases. Some 
specialists use polytetrafluoroethylene implants with an additional attached polymer impermeable liner to a tubular skeleton. The deformation criteria of such implants with liner do not meet biomechanics properties of human blood vessels.

Scientists of economically developed countries continue to research in this scientific direction. Practical researchers use various polymer materials in the implants. The main task is to produce vascular prostheses, which can ensure a normal long term hemodynamics in the reconstructed vascular system.

The main problem of modern vascular surgery is the absence of vascular implants with biochemical properties similar to properties of the human blood vessel.

In our case, the authors have continued to develop prosthetic devices that are closest to the properties of the human blood vessel.

In the process of scientific and practical work the authors suggested new models of implants.

Testing the new prosthesis effectively confirms a good modulus of elasticity and the prosthesis must possess excellent elastic properties in the longitudinal and radial directions. The developed innovative wall structure must provide all these properties, as well as allow partially degraded in vivo. This partial degradation of natural fibres will contribute to a better incorporation of live tissue in a synthetic wall.

All these properties are very important because implants of the new structure will function under pressure, ensuring normal hemodynamics.

This research was based on the previously conducted research in this area. The authors also take into account the huge international scientific expertise and basic scientific, practical work and publications in the field of the development of vascular implants.

\section{THE RAW MATERIALS FOR THE PRODUCTION OF VASCULAR IMPLANTS}

The geometric shapes of the prosthesis and prosthesis wall structure influence on its functionality. The practical implementation of the requirements of the implants also depends on the properties of the raw material. Properties of synthetic raw material influence on the desired properties of vascular tubular prostheses.

Any material that is used for vascular prostheses should include the following properties (Ailyn Tekin, 2009):

- Biocompatibility and non-immunogenicity;

- Long term chemical and mechanical stability;

- Processability;

- Viscoelastic properties similar to blood vessels;

- Adequate, manageable pore size and distribution;

- Prevent graft leakage which can lead to seroma formation and blood loss, be abrasion resistant;

- Promotes cell attachment and angiogenesis;

- Low toxicity, locally, systemically and from degradation products;

- Absorbable/Non-absorbable (depending on the situation);

- Ability to release bioactive compounds;

- Smooth blood flow surface.
The main requirements for tubular implants are indicated in international standards (Cardiovascular implants - Tubular vascular prostheses, ISO 7198:1998) and in some national standards (American National Standard): biocompability, biostability, thromboresistence, tissue incorporation, sterility, etc.

All synthetic implants are not entirely inert to living tissues. The main thing, bio-resistant fibrous materials can optimally operate without living tissue inflammation. Polyester, polyurethane, natural surgical silk are referred to as biologically non-toxic and mechanically compatible materials.

Natural silk sutures are relatively strong and elastic (elongation to break approximately $20 \%$ ). Natural silk yarn structure is destroyed at temperatures $175^{\circ} \mathrm{C}$. Natural silk completely dissolves in the living organism within two-three years. Bio-degradation depends on several factors: physical, chemical and biological, but the main role of the process of bio-degradation has the activity of enzymes. The effect of enzyme accelerates the process of destruction [4].

Natural silk sutures are also smooth. Surgical silk sutures are successfully used in the sewing together of implants with natural blood vessels. Natural silk threads are successfully used in plastic surgery and other surgical operations.

It has been scientifically proven that natural silk threads are able to provide the anti-thrombotic inner surface of the implant, as well as the normal flow of blood in the reconstructed vascular system. Hemodynamics and antithrombotic indicators of the vascular prosthesis made of natural silk are better than vascular PTFE prosthesis [5].

In the process of scientific and practical research [6] scientists found that natural silk vascular prostheses of small diameter $(1.5 \mathrm{~mm})$ successfully regulate blood pressure and blood flow in the body of the rat one year after the implantation.

Many international scientific studies confirm the suitability of natural silk material in surgery and medicine [7-20].

Silk surgical sutures are able to resist the effects of microorganisms, toxins and antibiotics. Natural silk is bio-resistant for a living organism. These yarns dissolve (bio destruction) within two to three years without adverse effects. The authors of this study have tested biomechanical characteristics of yarns made of natural silk. Such testing was necessary in order to properly use these yarns in wall innovative structure of the woven vascular implant. Testing of biomechanical properties was carried out on the test machine Zwick/Roel $500 \mathrm{~N}$ using a special computer program. In the course of the experiment natural silk yarns with linear density 10.00 Tex have been used.(See Figure 1).

The experimental results confirmed that natural silk surgical suture has good biochemical properties. For example, maximum strain: $\mathcal{E} \max =21.75 \%$. This material quite rightly can be used in the structure of vascular implants. 


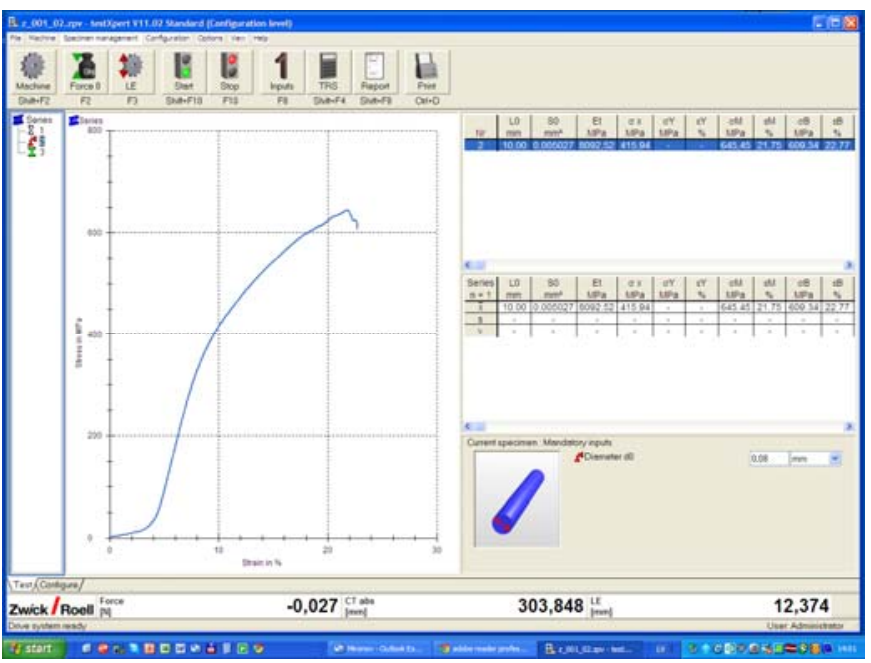

Fig.1. Dependence of strain and stress of natural silk surgical yarns (linear density $\mathrm{T}=10.00$ )

However, bio-absorption of these yarns contributes to normal hemodynamics in the reconstructed vascular system. Living tissue and small blood vessels will grow in the place of the dissolved filaments. Synthetic prosthesis will gradually be similar to the natural blood vessel.

\section{WOVEN VASCULAR IMPLANTS WITH INNOVATIVE WALL STRUCTURE}

The implant should be able to pulsate. It is a very important condition for its normal functioning. This means that the prosthesis must be able to deform under internal pressure at $10-15 \%$ in the radial direction.

The most important indicator is the modulus of elasticity of the implant. This parameter was studied during the testing of the new prototype. Modulus of elasticity of the implant should be similar to modulus of elasticity of human blood vessel.

During this practical research several samples of aortic implants were manufactured using the technology of weaving ( $2 / 2$ twill weave). Polyester, polyurethane and natural surgical silk were used in the process of weaving. (See Figure 2)

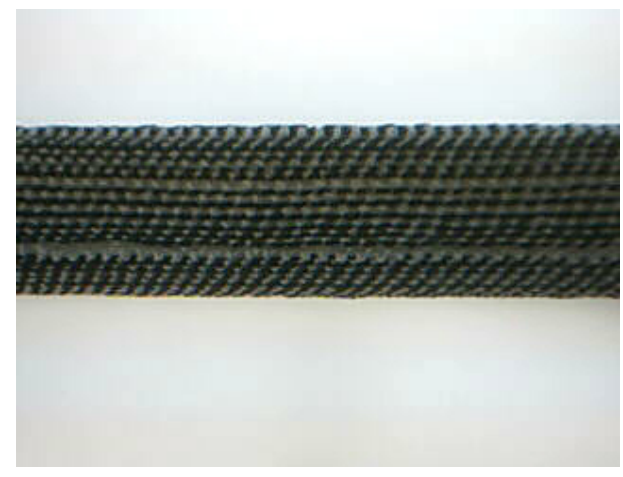

Fig.2. Prototype of innovative woven vascular implant
Warp system device. The first bundle consists of two polyurethane yarns and one polyester yarn. The next bundle consists of two polyurethane yarns and one surgical natural silk yarn. Eight bundles are inserted into one tooth of reed. Then three empty teeth of reed follow. Eight bundles into one tooth again follow after three blank teeth.

Weft system consists of only polyurethane yarns.

This device of yarn system and weft system provides the deformation properties of the woven prosthesis.

Samples of prostheses have been tested on a special load stand with fixing values of internal pressure, stress and strain.

The testing regimes were conventional - standard conditions.

This stand is equipped with a digital video camera. In the process of testing this equipment provides measurement and commits all indicators of stress and deformation, as well as visual modifications of the sample. Increment of loading is $20 \mathrm{mmHg}$. In the course of the experiment the load is gradually increased to a critical load value of $220 \mathrm{mmHg}$. (See Fig.3)

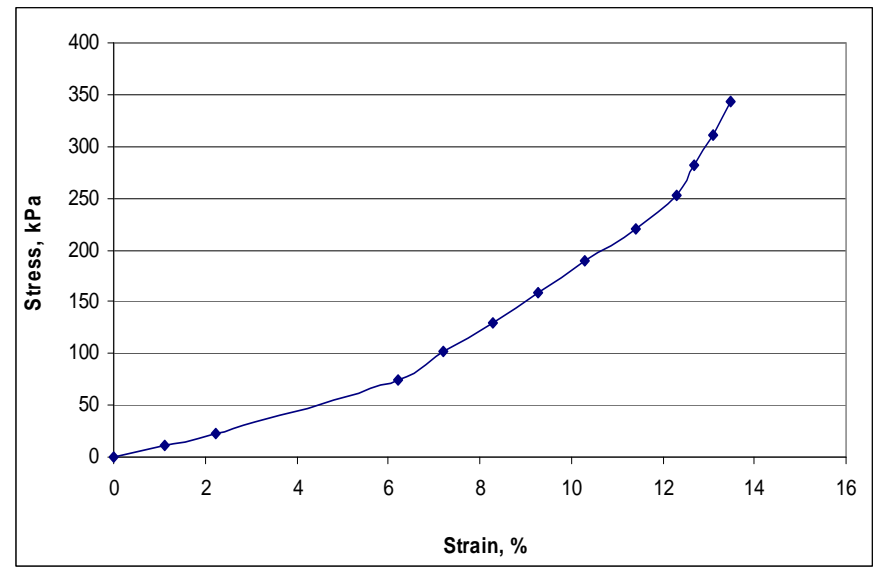

Fig.3. Dependence of strain and stress for vascular implant reinforced of natural silk yarns

Then the modulus of elasticity was calculated.

The test results show that the vascular implant reinforced with natural silk yarns is capable of normal pulsate. Modulus of elasticity of the implant under a normal pressure (100 $120 \mathrm{mmHg}$ ) is $2.92 \mathrm{MPa}$, but modulus of elasticity under the maximum critical pressure $(200-220 \mathrm{mmHg})$ is $6.75 \mathrm{Mpa}$. These figures $(\mathrm{E} 1=2.92 ; \mathrm{E} 2=6.75)$ compared with the human aorta elastic modulus $(\mathrm{E}=3.00-10.00 \mathrm{Mpa})$ are very good.

All other properties of the innovative product will be tested in the course of further research, including preclinical testing.

\section{V.CONCLUSIONS}

Modulus of elasticity, as the most accurate parameter of biomechanical properties, confirms that these prostheses can ensure a long-term normal hemodynamics in restored vascular system. Reinforced with natural silk yarns the structure of an implant should provide a better integration of the prosthesis into living tissue. 


\section{REFERENCES}

1. Dattilo, P. P., King, M. W., Cassill, N. L., Leung, J. C. Medical Textiles: Application of an Absorbable Barbed Bi-directional Surgical Suture. Journal of Textile and Apparel, Technology and Management. Volume 2, Issue 2. USA NC State University. 2002.

2. Heim, F., Durand, B., Chakfe N. Textile for heart valve prostheses: fabric long-term durability testing. Journal Biomedical Materials Research Part B: Applied Biomaterials. 92 (1), 2010, pp.68-77. http://dx.doi.org/10.1002/jbm.b.31490

3. Heim, F., Durand, B., Chakfe, N. Textile Heart Valve Prosthesis: From Fabric Design Criteria to Early In-Vivo Performances. The Journal of Heart Valve Disease. 22, 2013, pp. 361-367.

4. Yang, Cao, Bochu, Wang. Biodegradation of Silk Biomaterials. International Journal of Molecular Sciences. Volume 10, Issue 4, 2009, pp. 1514-1524.

5. Enomoto, S., et al. Long-term patency of small-diameter vascular graft made from fibroin, a silk-based biodegradable material. Journal of Vascular Surgery. Volume 51, Issue 1, 2010, pp. 155-164. http://dx.doi.org/10.1016/i.jvs.2009.09.005

6. Lovett, M., et al. Tubular silk scaffolds for small diameter vascular grafts. Landes Bioscience Journal Organogenesis. Volume 6, Issue 4, 2010, pp. 217-224.

7. Zhang, Q., Yan, S., and Li, M. Silk Fibroin Based Porous Materials. Materials. Volume 2, No.4, 2009, pp. 2276-2295. http://dx.doi.org/10.3390/ma2042276

8. Holmes, T. C. Novel Peptide-Based Biomaterial Scaffolds for Tissue Engineering. Trends in Biotechnology. Volume 20, No.1, 2002, pp. 1621. http://dx.doi.org/10.1016/S0167-7799(01)01840-6

9. Wenk, E., Markle, H. P., and Meinel, L. Silk Fibroin as a Vehicle for Drug Delivery Applications. Journal of Controlled Release. Volume 150, No.2, 2011, 2 pp. http://dx.doi.org/10.1016/j.jconrel.2010.11.007

10. Altman, G. H., Diaz, F., Jakuba, C., et al. Silk-Based Biomaterials. Biomaterials. International Journal of Environmental Science and Development. Volume 24, No.3, 2003, pp. 401-416.

11. Dyakonov, T., et al. Design and Characterization of a Silk-FibroinBased Drug Delivery Platform Using Naproxen as a Model Drug. Journal of Drug Delivery. Volume 2012, $10 \mathrm{p}$.

12. Matsumoto, A., et al. Mechanisms of Silk Fibroin Sol-Gel Transitions. The Journal of Physical Chemistry. Volume 110 (43), 2006, pp. 2163021638. http://dx.doi.org/10.1021/jp056350v

13. Li, M., et al. Structure and Properties of Silk Fibroin Poly (Vinyl Alcohol) Gel. International Journal of Biological Macromolecules. Volume 30, Issue 2, 2002, pp. 89-94. http://dx.doi.org/10.1016/S01418130(02)00007-7 Zhang, Q., et al. Study on Silk Fibroin Gelation: Effect of Polyalcohol. Advanced Materials Research. Volumes 175-176, 2011, pp. 137-142.

14. Wang, H., et al. The Properties of Native Silk Fibroin (SF) Solution / Gel from Bombyx mori Silkworms During the Full Fifth Instar Larva Stage. Journal of Wuhan University of Technology - Materials Science Edition. Volume 26, Number 2, 2011, pp. 262-268. http://dx.doi.org/10.4028/www.scientific.net/AMR.175-176.137
15. Craig, K., et al. Anti-Thrombogenic Modification of Small-Diameter Microfibrous Vascular Grafts. Arteriosclerosis, Thrombosis, and Vascular Biology - Journal of the American Heart Association. 30, 2010, pp. 1621-1627.

16. Sato, M., et al. Small-Diameter Vascular Grafts of Bombyx Mori Silk Fibroin Prepared by a Combination of Electrospinning and Sponge Coating. Material Letters. Volume 64, Issue 16, 2010, pp. 1786-1788.

17. Nakazawa, Y., Asakura, T. Development of the Tissue Engineered Medical Products Based on Silk Fibroin from Bombyx mori and Transgenic Silkworm. Journal of The Society of Fiber Science and Technology, Japan. Volume 65, Issue 1, 2009, pp. 11-13. http://dx.doi.org/10.1016/j.matlet.2010.05.024

18. Nakazawa, Y., et al. Development of Small-Diameter Vascular Grafts Based on Silk Fibroin Fibres from Bombyx mori for Vascular Regeneration. Journal of Biomaterials Science. Volume 22, 2011, pp. 195

19. Asakura, T., et al. Development of Small-Diameter Graft Made from Silk Fibroin. The Society of Polymer Science, Japan. Polymers - Hot Topics in Polymer Science in Japan, January. Volume 59, No. 12010, http://dx.doi.org/10.1163/092050609X12586381656530

20. Guan, G., et al. Cellular Compatibility and Hemocompatibility of Silk Fibroin-PET Based Small Diameter Vascular Graft. In: FiberMed11 International Conference on Fibrous Products in Medical and Health Care. June 28-30, 2011, Tampere, Finland.

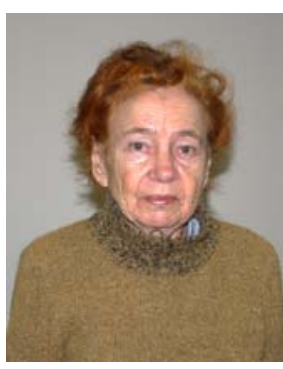

Viktoriya Kancevicha

Lead Researcher

Riga Technical University

Scientific degree: Dr. habil. sc. ing. (1994, H$11, \mathrm{RTU})$

Research direction: Vascular implant manufacturing and properties research Address: Riga Technical University, Institute of Textile Materials Technologies and Design, Azenes Str. 18, Riga, LV-1048, Latvia E-mail: Viktorija.Kancevica@rtu.lv

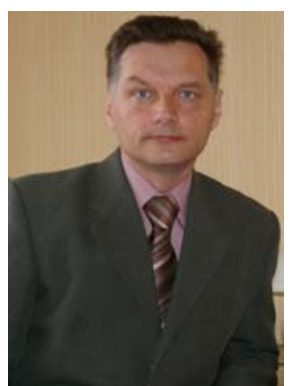

\section{Andreys Lukyanchikovs}

Lead Researcher

Riga Technical University

Scientific degree: Dr. sc. ing. (1998, H-11, RTU)

Research direction: Vascular implant manufacturing and properties research Address: Riga Technical University, Institute of Textile Materials Technologies and Design, Azenes Str. 18, Riga, LV-1048, Latvia E-mail: Andrejs.Lukjancikovs@rtu.lv

Viktorija Kanceviča, Andrejs Lukjančikovs. Asinsvadu implanti armēti ar dabīgā zīda ķirurgískiem pavedieniem

Šajā praktiski-zinātniskajā darbā tika izstrādātas austas asinsvadu protēzes, kuru struktūrā iestrādāti armējoši dabiskā zīda ķirurğiskie pavedieni. Šo pavedienu biomehāniskās īpašības uzrādīja labus elastības un sprieguma raksturlielumus. Izmantojot iepriekšējo pieredzi, kad tika izgatavotas asinsvadu protēzes no kompleksiem poliestera un mono poliuretāna pavedieniem, izstrādājām inovatīvas struktūras protēžu sieninas. Šo asinsvadu protēžu sieninas sastāvēja no poliestera, poliuretāna un dabiskā zīda ķirurǵiskiem pavedieniem. Pēdējie pēc dažu gadu funkcionēšanas dzīvā organīsmā uzsūcas bez kaitīgām sekām un to vietā ieaug dabīgie audi. Šādas struktūras asinsvadu protēzes galvenais biomehāniskais parametrs, elastības modulis, ir pēc savas vêrtības tuvāks cilvēka asinsvada elastības modulim. Inovatīvas struktūras asinsvadu protēzes spēs ilgstoši nodrošināt normālu hemodinamiku.

\section{Виктория Канцевича, Андрей Лукьянчков. Васкулярные импланты, армированные нитями натурального шелка}

В ходе реализации данной научно-практической работы были спроектированы и изготовлены тканые синтетические протезы, армированные нитями натурального шелка. При проектировании структуры стенки протеза исследовались биомеханические свойства хирургических натуральных шелковых нитей. В результате лабораторного эксперимента были получены хорошие показатели эластичности и напряжения исследуемых образцов натуральных нитей. Вместе с тем, при проектировании был использован предыдущий практический опыт изготовления различных васкулярных протезов, состоящих из комплексных полиэфирных и полиуретановых мононитей. В результате произведенной работы авторами была предложена комбинированная структура стенки васкулярного протеза, состоящая из полиэфирных, полиуретановых, и натуральных шелковых хирургических нитей. После имплантации синтетического протеза, армированного хирургическими натуральными шелковыми нитями, последние полностью рассасываются в организме в течение нескольких лет. При этом происходит постепенное врастание живых клеток и тканей организма в структуру стенки синтетического протеза. Экспериментальные лабораторные исследования подтвердили, что главный биомеханический параметр изготовленного протеза, модуль эластичности, по своим значениям близок показателю модуля эластичности кровеносного сосуда человека. Инновационная структура комбинированного протеза кровеносного сосуда, обладающая такими параметрами, способна долгосрочно обеспечивать нормальную гемодинамику в условиях реконструированной кровеносной системы. 